\title{
Sistem Penunjang Keputusan Penyeleksian Quality Assurance Tester Menggunakan Metode Analytical Hierarchy Process (Studi Kasus : PT. Gameloft Indonesia Yogyakarta)
}

\author{
Edwin Rafiza Pradana Nasution ${ }^{1}$, A. Sidiq Purnomo ${ }^{2}$ \\ ${ }^{1}$ Informatika, Teknologi Informasi, Universitas Mercu Buana Yogyakarta \\ ${ }^{2}$ Informatika, Teknologi Informasi, Universitas Mercu Buana Yogyakarta \\ ${ }^{1} 16111016 @$ student.mercubuana-yogya.ac.id, ${ }^{2}$ sidiq@mercubuana-yogya.ac.id
}

\begin{abstract}
The selection of new employees in a company is very important because it determines the quality of the company. One of the effective ways in selecting employees is by implementing a decision support system so that they can decide with the right results in selecting new employees. This application applies the Analytical Hierarchy Process (AHP) method, namely by weighting the criteria and applicants. The results of the study are in the form of a new employee selection system application that provides recommendations as consideration for making appropriate decisions and is expected to facilitate the process of selecting new employees. Based on the test results, this system is able to perform calculations and rankings in the selection of Quality Assurance Tester according to manual calculations from PT Gameloft Indonesia with an accuracy of $86 \%$.
\end{abstract}

Keywords: AHP, Employee Selection, PT Gameloft Indonesia, Quality Assurance Tester, Decision Support System.

\begin{abstract}
Abstrak
Pemilihan karyawan baru dalam suatu perusahaan merupakan suatu hal yang sangat penting karena menentukan kualitas perusahaan tersebut. Salah satu cara yang efektif dalam menyeleksi karyawan adalah dengan cara menerapkan sistem penunjang keputusan sehingga dapat memutuskan dengan hasil yang tepat dalam menyeleksi karyawan baru. Aplikasi ini menerapkan metode Analytical Hierarchy Process (AHP), yaitu dengan melakukan pembobotan terhadap kriteria dan pelamar. Hasil penelitian berupa aplikasi sistem pemilihan karyawan baru yang memberikan rekomendasi sebagai bahan pertimbangan untuk mengambil keputusan secara tepat dan diharapkan dapat mempermudah proses seleksi karyawan baru. Berdasarkan hasil pengujian, sistem ini mampu melakukan perhitungan dan perankingan dalam penyeleksian Quality Assurance Tester sesuai dengan perhitungan manual dari PT Gameloft Indonesia dengan ketepatan 86\%.
\end{abstract}

Kata kunci: AHP, Pemilihan Karyawan, PT Gameloft Indonesia, Quality Assurance Tester, Sistem Pendukung Keputusan.

\section{Pendahuluan}

\subsection{Latar Belakang}

Dalam rangka meningkatkan kualitas permainan dari sisi pengujian, maka PT Gameloft Indonesia ingin mendapatkan penguji yang handal dalam melakukan pengujian. Sehingga diperlukan sebuah sistem yang dapat mendukung pembuatan keputusan dalam seleksi pemilihan Quality Assurance Tester. Dengan adanya sistem ini diharapkan pengambil keputusan tidak mengalami kesulitan dalam menentukan pelamar yang akan diterima dan mengurangi kesalahan dalam mengambil keputusan memilih pelamar yang tidak kompeten. Sistem pendukung keputusan adalah teknik yang dapat mengotomasi pembuatan sebuah keputusan [2]. Sistem pendukung keputusan dapat memungkinkan pembuatan keputusan lebih konsisten dan efisien. Di dalam beberapa penelitian, sistem pendukung keputusan telah digunakan untuk menentukan penerima bantuan Covid 19 [8], penentuan matakuliah pilihan [11], pemilihan kategori promosi produk [5], pemilihan investasi saham [12] dan pemilihan guru terbaik [9].
Analytical Hierarchy Process (AHP) adalah metode sistem pendukung keputusan yang menguraikan masalah dengan banyak kriteria yang kompleks menjadi suatu hirarki sehingga permasalahan menjadi lebih terstruktur dan sistematis.

Rumusan masalah dalam penelitian ini adalah bagai mana perancangan dan pembangunan sistem pendukung keputusan, serta penerapan metode Analytical Hierarchy Process dalam penyeleksian Quality Assurance Tester di PT Gameloft Indonesia.

Tujuan dilakukannya penelitian ini adalah untuk membangun dan merancang sistem pendukung keputusan penyeleksian Quality Assurance Tester di PT Gameloft Indonesia dengan menggunakan metode Analytical Hierarchy Process. Penelitian ini diharapkan dapat memberi manfaat untuk pemecahan masalah yang dialami oleh PT Gameloft Indonesia pada saat penyeleksian Quality Assurance Tester dengan merancang dan membangun sistem yang sesuai. 


\subsection{Tinjauan Pustaka}

Penelitian terdahulu yang menjadi acuan pada penelitian ini salah satunya adalah penelitian mengenai sistem pendukung keputusan perekrutan karyawan dengan metode Simple Additive Weighting (SAW) [7]. Penelitian ini dilakukan di PT. Cakra Mobilindo. Kriteria yang digunakan adalah IPK, nilai tes kompetensi, psikotes, kemampuan dasar dan interview. Perancangan sistem menggunakan diagram use case dan class. Sistem yang dibangun adalah sistem berbasis web. Penelitian ini menghasilkan sistem pendukung keputusan untuk perekrutan karyawan. Pengujian sistem dilakukan dengan metode kuisioner. Kesimpulan yang dibuat adalah sistem yang telah dibangun dapat membantu pengguna dalam melakukan perekrutan karyawan.

Selanjutnya adalah penelitian mengenai sistem pendukung keputusan pemilihan pegawai honorer dengan metode MFEP (Multi Factor Evaluation Process) [10]. Penelitian dilakukan di Kelurahan Babura. Kriteria yang digunakan adalah pendidikan, umur, jarak dan tinggi badan. Tahap penelitian yang dilakukan adalah studi literatur, analisa, pembahasan dan pengujian. Kesimpulan yang dibuat adalah metode MFEP dapat digunakan dalam menentukan calon pegawai honor pada Kelurahan Babura.

Penelitian ini fokus terhadap sistem pendukung keputusan penyeleksian quality assurance tester dengan menggunakan metode Analytical Hierarchy Process (AHP). Penelitian akan dilakukan di PT Gameloft Kota Yogyakrta, Daerah Istimewa Yogyakarta. Sistem yang akan dibangun merupakan sistem berbasis desktop untuk sistem operasi Windows. Sistem akan dibangun menggunakan bahasa C++ pada Visual Studio 2015 Community Edition dan basis data dari Microsoft Access. Metode pengembangan sistem menggunakan Waterfall. Pengujian yang akan digunakan adalah pengujian blackbox dan perhitungan.

\subsection{Landasan Teori}

Penguji jaminan kualitas (Quality Assurance Tester) permainan adalah orang yang menguji permainan dan melaporkan masalah yang ditemukan kepada produsen. Produser harus memastikan bahwa programer bekerja sama dengan penguji jaminan kualitas. Penguji melakukan berbagai pengujian selama silus pengembangan permainan. Penguji dapat memainkan permainan selama berjam-jam untuk menemukan berbagai kesalahan. Ketika penguji menemukan tanggapan atau tindakan yang tidak terduga maka programer dapat memeriksa ulang persamaan yang menyebabkan kejadian ini. Penguji juga melaporkan secara rinci setiap masalah yang mereka temukan atau saran yang mereka miliki baik secara lisan maupun tertulis kepada supervisor [4].

Sistem pendukung keputusan adalah sistem yang membantu pengambil keputusan dalam menyelesaikan masalah. Sistem ini merupakan sistem berbasis komputer yang interaktif dan merupakan bagian dari sistem informasi berbasis komputer. Sistem ini dapat menyelesaikan masalah tak terstruktur dan semi terstruktur. Sistem ini memanfaatkan data dan model dalam menyelesaikan masalah. Model sistem pendukung keputusan terdiri atas banyak prosedur yang berfungsi dalam mengambil keputusan [6].

Analytic Hierarchy Process (AHP) adalah metode perhitungan untuk pengambilan keputusan yang mempertimbangan faktor logika, intuisi, pengalaman, pengetahuan, emosi dan rasa. Faktor-faktor ini dioptimasi dalam suatu proses yang sistematis. Metode ini mampu membandingkan data kualitatif dan kuantitatif. Metode ini mampu menggunakan data dengan skala nominal, ordinal, interval dan rasio [3].

Rekayasa perangkat lunak (RPL) adalah ilmu yang mempelajari cara pengembangan perangkat lunak dari tahap pembuatan, pemeliharaan, manajemen organisasi pengembangan perangkat lunak sampai manajemen kualitas. Rekayasa perangkat lunak menerapkan pedekatan yang sistematis, teratur dan terukur untuk pengembangan, penggunaan dan pemeliharan perangkat lunak. Rekayasa perangkat lunak harus mengacu kriteria perangkat lunak yang dapat dirawat dan dipelihara, dapat mengikuti perkembangan teknologi, dapat mengikuti keinginan pengguna, efektif dan efisien dalam penggunaanya, serta dapat memenuhi kebutuhan yang diinginkan [1]. Dalam implementasi nya, Informasi hasil dari sistem bukanlah hal yang menjadi patokan, pengambilan keputusan tetap berada pada pengambil keputusan. Sistem hanya menghasilkan keluaran yang mengkalkulasi data-data sebagaimana perhitungan seorang pengambil keputusan. Sehingga kerja pengambil keputusan dapat dimudahkan.

Berdasarkan hasil perangkingan yang telah diperoleh menggunakan metode AHP tersebut, selanjutnya hasil tersebut dapat diujikan dengan membandingakan hasil kerja sistem dengan perhitungan manual, seperti pada Persamaan 1 :

Persentase $=\frac{\text { Data Sesuai }}{\text { Jumlah Total Data }} \times 100 \%$

\section{Metode Penelitian}

\subsection{Data Penelitian}

Bahan penelitian yang diperlukan dalam penelitian ini adalah data primer dan data sekunder. Data primer yang diambil dengan metode wawancara terhadap bagian sumber daya manusia PT Gameloft Indonesia. Data yang diperlukan adalah data mengenai kriteria dan subkriteria yang digunakan dalam mengambil keputusan penyeleksian quality assurance tester. Data sekunder yang diambil dengan metode pengamatan terhadap berkas lamaran quality assurance tester. Data yang diperlukan adalah adalah data mengenai pelamar. 


\subsection{Tahap Penelitian}

Penelitian yang akan dilakukan merupakan penelitian pengembangan sistem sehingga jalannya penelitian sesuai dengan tahap metode pengembangan sistem yang akan digunakan. Metode pengembangan sistem yang akan digunakan dalam penelitian ini adalah waterfall. Tahap pada metode waterfall yang akan digunakan adalah analisis, desain, coding, testing dan maintenance. Tahap pembangunan sistem dalam penelitian ini dapat dilihat pada gambar 1 .

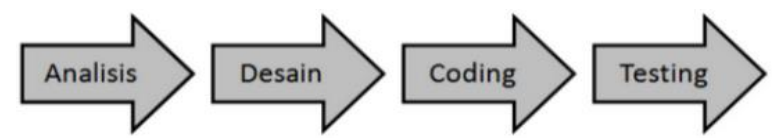

Gambar 1. Tahap pembangunan sistem

Dalam penelitian kali ini, peneliti menggunakan empat (4) kriteria yaitu Bug Finding, Bug Isolation, Bug Description dan Bug Reporting, dengan masing masing kriteria memiliki empat (4) subkriteria. Tabel 1 merupakan tabel kriteria, dan tabel 2, 3, 4 merupakan tabel sub kriteria.

Tabel 1. Tabel Kriteria

\begin{tabular}{|c|c|c|c|}
\hline & & & \\
\hline & No & \multicolumn{2}{|l|}{ Nama kriteria } \\
\hline & 1 & \multicolumn{2}{|l|}{ Bug Finding } \\
\hline & 2 & \multicolumn{2}{|l|}{ Bug Isolation } \\
\hline & 3 & \multicolumn{2}{|l|}{ Bug Description } \\
\hline & 4 & \multicolumn{2}{|l|}{ Bug Reporting } \\
\hline \multicolumn{4}{|c|}{ Tabel 2. Sub Kriteria Bug Finding } \\
\hline No & & Keterangan \\
\hline 1 & \multicolumn{2}{|c|}{ Sangat Menguasai } & $\begin{array}{l}\text { Sangat bisa } \\
\text { menemukan } \\
\text { kesalahan }\end{array}$ \\
\hline 2 & \multicolumn{2}{|c|}{ Menguasai } & $\begin{array}{l}\text { Bisa } \\
\text { menemukan } \\
\text { kesalahan }\end{array}$ \\
\hline 3 & \multicolumn{2}{|c|}{ Kurang Menguasai } & $\begin{array}{l}\text { Kurang bisa } \\
\text { menemukan } \\
\text { kesalahan }\end{array}$ \\
\hline 4 & \multicolumn{2}{|c|}{ Tidak Bisa } & $\begin{array}{l}\text { Tidak Bisa } \\
\text { menemukan } \\
\text { kesalahan }\end{array}$ \\
\hline \multicolumn{4}{|c|}{ Tabel 3. Sub Kriteria Bug Isolation } \\
\hline No & \multicolumn{2}{|c|}{ Nama sub kriteria } & Keterangan \\
\hline 1 & \multicolumn{2}{|c|}{ Sangat Menguasai } & $\begin{array}{l}\text { Sangat bisa } \\
\text { menemukan } \\
\text { kesalahan }\end{array}$ \\
\hline 2 & \multicolumn{2}{|c|}{ Menguasai } & $\begin{array}{l}\text { Bisa } \\
\text { menemukan } \\
\text { kesalahan }\end{array}$ \\
\hline 3 & \multicolumn{2}{|c|}{ Kurang Menguasai } & $\begin{array}{l}\text { Kurang bisa } \\
\text { menemukan } \\
\text { kesalahan }\end{array}$ \\
\hline 4 & \multicolumn{2}{|c|}{ Tidak Bisa } & $\begin{array}{l}\text { Tidak Bisa } \\
\text { menemukan } \\
\text { kesalahan }\end{array}$ \\
\hline \multicolumn{4}{|c|}{ Tabel 4. Sub Kriteria Bug Description } \\
\hline No & \multicolumn{2}{|c|}{ Nama sub kriteria } & Keterangan \\
\hline 1 & \multicolumn{2}{|c|}{ Sangat Jelas } & $\begin{array}{l}\text { Sangat bisa } \\
\text { menjelaskan } \\
\text { kesalahan }\end{array}$ \\
\hline 2 & \multicolumn{2}{|l|}{ Jelas } & $\begin{array}{l}\text { Bisa } \\
\text { menjelaskan } \\
\text { kesalahan }\end{array}$ \\
\hline
\end{tabular}

\begin{tabular}{lll}
\hline 3 & Kurang Jelas & $\begin{array}{l}\text { Kurang bisa } \\
\text { menjelaskan } \\
\text { kesalahan }\end{array}$ \\
\hline $\mathbf{4}$ & Tidak Bisa & $\begin{array}{l}\text { Tidak bisa } \\
\text { menjelaskan } \\
\text { kesalahan }\end{array}$ \\
\hline
\end{tabular}

Tabel 5. Sub Kriteria Bug Reporting

\begin{tabular}{lll}
\hline No & Nama sub kriteria & Keterangan \\
\hline $\mathbf{1}$ & Sangat Jelas & $\begin{array}{l}\text { Sangat bisa } \\
\text { menjelaskan } \\
\text { kesalahan }\end{array}$ \\
\hline $\mathbf{2}$ & Jelas & $\begin{array}{l}\text { Bisa } \\
\text { menjelaskan } \\
\text { kesalahan }\end{array}$ \\
\hline $\mathbf{3}$ & Kurang Jelas & $\begin{array}{l}\text { Kurang bisa } \\
\text { menjelaskan } \\
\end{array}$ \\
& & kesalahan \\
\hline $\mathbf{4}$ & Tidak Bisa & $\begin{array}{l}\text { Tidak bisa } \\
\text { menjelaskan } \\
\end{array}$ \\
& & kesalahan \\
\hline
\end{tabular}

Matriks perbandingan berpasangan kriteria yang akan digunakan dapat dilihat pada tabel 6 .

Tabel 6. Matriks Perbandingan Berpasangan Kriteria

\begin{tabular}{llllll}
\hline $\mathbf{N}$ & $\begin{array}{l}\text { Nama } \\
\mathbf{0}\end{array}$ & $\begin{array}{l}\text { Bug } \\
\text { Kriteria } \\
\mathbf{g}\end{array}$ & $\begin{array}{l}\text { Bug } \\
\text { Isolatio } \\
\text { n }\end{array}$ & $\begin{array}{l}\text { Bug } \\
\text { Descripti } \\
\text { on }\end{array}$ & $\begin{array}{l}\text { Bug } \\
\text { Reporti } \\
\text { ng }\end{array}$ \\
\hline $\mathbf{1}$ & $\begin{array}{l}\text { Bug } \\
\text { Finding }\end{array}$ & 1 & 1 & 2 & 3 \\
\hline $\mathbf{2}$ & $\begin{array}{l}\text { Bug } \\
\text { Isolation }\end{array}$ & 1 & 1 & 1 & 2 \\
\hline $\mathbf{3}$ & $\begin{array}{l}\text { Bug } \\
\text { Descripti } \\
\text { on }\end{array}$ & $1 / 2$ & 1 & 1 & 1 \\
\hline $\mathbf{4}$ & $\begin{array}{l}\text { Bug } \\
\text { Rerportin } \\
\text { g }\end{array}$ & $1 / 3$ & $1 / 2$ & 1 & 1 \\
\hline
\end{tabular}

Matriks perbandingan berpasangan sub kriteria bug finding yang akan digunakan ditunjukan oleh tabel 7

Tabel 7 Matriks Perbandingan Berpasangan Sub Kriteria Bug Finding

\begin{tabular}{llllll}
\hline $\begin{array}{l}\text { N } \\
\mathbf{0}\end{array}$ & $\begin{array}{l}\text { Nama } \\
\text { Kriteria }\end{array}$ & $\begin{array}{l}\text { Sangat } \\
\text { Menguas } \\
\text { ai }\end{array}$ & $\begin{array}{l}\text { Menguas } \\
\text { ai }\end{array}$ & $\begin{array}{l}\text { Kurang } \\
\text { Menguas } \\
\text { ai }\end{array}$ & $\begin{array}{l}\text { Tida } \\
\mathbf{k} \\
\text { Bisa }\end{array}$ \\
\hline $\mathbf{1}$ & $\begin{array}{l}\text { Sangat } \\
\text { Menguas } \\
\text { ai }\end{array}$ & 1 & 1 & 2 & 3 \\
\hline $\mathbf{2}$ & $\begin{array}{l}\text { Menguas } \\
\text { ai }\end{array}$ & 1 & 1 & 1 & 2 \\
\hline $\mathbf{3}$ & $\begin{array}{l}\text { Kurang } \\
\text { Mneguas } \\
\text { ai }\end{array}$ & $1 / 2$ & 1 & 1 & 1 \\
\hline $\mathbf{4}$ & $\begin{array}{l}\text { Tidak } \\
\text { Bisa }\end{array}$ & $1 / 3$ & $1 / 2$ & 1 & 1 \\
\hline
\end{tabular}

Matriks perbandingan berpasangan sub kriteria bug isolation, bug description, dan bug reporting yang akan digunakan hampir sama dengan matriks perebandingan berpasangan sub kriteria bug finding sehingga tidak di uraikan lebih lanjut. Perbedaannya adalah pada nama sub kritera sedangkan nilai perbandingan pada matriks sama. 


\subsection{Pengambilan Keputusan}

Berikut adalah nilai yang digunakan sebagai nilai pembanding, nilai berikut merupakan nilai perhitungan manual yang di dapat dari PT Gameloft Indonesia Yogyakarta. Nilai dari 50 data tersebut dapat dilihat pada tabel 8

Tabel 8. Nilai Pelamar dari PT Gameloft

\begin{tabular}{|c|c|c|c|c|c|c|}
\hline $\begin{array}{l}\mathbf{N} \\
\mathbf{0}\end{array}$ & $\begin{array}{l}\text { Pelama } \\
\mathbf{r}\end{array}$ & $\begin{array}{l}\text { Bug } \\
\text { Find } \\
\text { ing }\end{array}$ & $\begin{array}{l}\text { Bug } \\
\text { Isolati } \\
\text { on }\end{array}$ & $\begin{array}{l}\text { Bug } \\
\text { Descripti } \\
\text { on }\end{array}$ & $\begin{array}{l}\text { Bug } \\
\text { Repo } \\
\text { rting }\end{array}$ & $\begin{array}{l}\text { Nilai } \\
\text { Total }\end{array}$ \\
\hline 1 & $\begin{array}{l}\text { Lumba } \\
\mathrm{n} \text { Batu } \\
\text { Heri }\end{array}$ & 85 & 85 & 60 & 85 & 78,75 \\
\hline 2 & $\begin{array}{l}\text { Juniska } \\
\text { Era }\end{array}$ & 85 & 70 & 85 & 70 & 77,5 \\
\hline 3 & Utara & 85 & 85 & 70 & 50 & 72,5 \\
\hline 4 & $\begin{array}{l}\text { Fitri } \\
\text { Angga }\end{array}$ & 85 & 85 & 60 & 50 & 70 \\
\hline 5 & $\begin{array}{l}\text { Ahmad } \\
\text { Erlangg } \\
\text { a }\end{array}$ & 85 & 80 & 60 & 50 & 68,75 \\
\hline 6 & $\begin{array}{l}\text { Novian } \\
\text { syah } \\
\text { Sacilia }\end{array}$ & 85 & 70 & 55 & 65 & 68,75 \\
\hline 7 & $\begin{array}{l}\text { Mawar } \\
\text { ni Bayu }\end{array}$ & 85 & 55 & 80 & 55 & 68,75 \\
\hline 8 & $\begin{array}{l}\text { Ella } \\
\text { Ramad } \\
\text { han }\end{array}$ & 80 & 75 & 55 & 65 & 68,75 \\
\hline 9 & $\begin{array}{l}\text { Munthe } \\
\text { Robi }\end{array}$ & 85 & 55 & 82 & 50 & 68 \\
\hline 10 & $\begin{array}{l}\text { Kurnia } \\
\text { Ferry }\end{array}$ & 74 & 74 & 78 & 45 & 67,75 \\
\hline 11 & $\begin{array}{l}\text { Super } \\
\text { Muham } \\
\text { mad }\end{array}$ & 85 & 64 & 45 & 75 & 67,25 \\
\hline 12 & $\begin{array}{l}\text { Rohani } \\
\text { Nurul }\end{array}$ & 85 & 50 & 65 & 67 & 66,75 \\
\hline 13 & $\begin{array}{l}\text { Faritz } \\
\text { Ridha } \\
\text { Dian }\end{array}$ & 82 & 65 & 64 & 55 & 66,5 \\
\hline 14 & $\begin{array}{l}\text { Wuland } \\
\text { ari Riri }\end{array}$ & 55 & 66 & 66 & 79 & 66,5 \\
\hline 15 & $\begin{array}{l}\text { Sihomb } \\
\text { ing Desi }\end{array}$ & 85 & 64 & 45 & 70 & 66 \\
\hline 16 & $\begin{array}{l}\text { Pramest } \\
\text { i M. }\end{array}$ & 85 & 50 & 74 & 55 & 66 \\
\hline 17 & $\begin{array}{l}\text { Arpan } \\
\text { Ayu }\end{array}$ & 64 & 75 & 60 & 65 & 66 \\
\hline 18 & $\begin{array}{l}\text { Mislaili } \\
\text { Dwi }\end{array}$ & 70 & 85 & 54 & 54 & 65,75 \\
\hline 19 & $\begin{array}{l}\text { Rosha } \\
\text { Pangest } \\
\text { u } \\
\text { Ahmad }\end{array}$ & 60 & 60 & 77 & 65 & 65,5 \\
\hline 20 & $\begin{array}{l}\text { Ramaya } \\
\text { ni Nur }\end{array}$ & 65 & 64 & 68 & 64 & 65,25 \\
\hline 21 & $\begin{array}{l}\text { Nuraini } \\
\text { Dewi }\end{array}$ & 60 & 50 & 75 & 75 & 65 \\
\hline 22 & $\begin{array}{l}\text { Riski } \\
\text { Randa }\end{array}$ & 70 & 54 & 85 & 50 & 64,75 \\
\hline 23 & $\begin{array}{l}\text { Karuniy } \\
\text { ati } \\
\text { Muham } \\
\text { ad }\end{array}$ & 80 & 74 & 54 & 50 & 64,5 \\
\hline 24 & Apriani & 50 & 85 & 55 & 65 & 63,75 \\
\hline 25 & $\begin{array}{l}\text { Riati } \\
\text { Ginting } \\
\text { Fitri }\end{array}$ & 65 & 50 & 55 & 85 & 63,75 \\
\hline 26 & $\begin{array}{l}\text { Raslan } \\
\text { Gatot }\end{array}$ & 65 & 50 & 55 & 80 & 62,5 \\
\hline
\end{tabular}

\begin{tabular}{|c|c|c|c|c|c|c|}
\hline 27 & $\begin{array}{l}\text { Ristiana } \\
\text { Tama } \\
\text { Jefry }\end{array}$ & 64 & 75 & 50 & 60 & 62,25 \\
\hline 28 & $\begin{array}{l}\text { Rohma } \\
\text { wati } \\
\text { Alvin }\end{array}$ & 74 & 74 & 50 & 50 & 62 \\
\hline 29 & $\begin{array}{l}\text { Mutiara } \\
\text { Kencan } \\
\text { a Sandi }\end{array}$ & 55 & 55 & 72 & 65 & 61,75 \\
\hline 30 & $\begin{array}{l}\text { Ismawa } \\
\text { ti }\end{array}$ & 65 & 64 & 50 & 65 & 61 \\
\hline 31 & $\begin{array}{l}\text { Reksos } \\
\text { amudro } \\
\text { Andika }\end{array}$ & 50 & 80 & 55 & 58 & 60,75 \\
\hline 32 & $\begin{array}{l}\text { Nababa } \\
\text { n Ilham }\end{array}$ & 70 & 50 & 50 & 72 & 60,5 \\
\hline 33 & $\begin{array}{l}\text { Fitriya } \\
\text { Afria }\end{array}$ & 45 & 45 & 75 & 75 & 60 \\
\hline 34 & $\begin{array}{l}\text { Kurnia } \\
\text { Awalia }\end{array}$ & 55 & 55 & 55 & 75 & 60 \\
\hline 35 & $\begin{array}{l}\text { Saputri } \\
\text { Indah }\end{array}$ & 70 & 55 & 55 & 52 & 58 \\
\hline 36 & $\begin{array}{l}\text { Afrida } \\
\text { Safitri }\end{array}$ & 54 & 70 & 51 & 56 & 57,75 \\
\hline 37 & $\begin{array}{l}\text { Nuratik } \\
\text { a Dwi }\end{array}$ & 40 & 65 & 55 & 70 & 57,5 \\
\hline 38 & $\begin{array}{l}\text { Riawan } \\
\text { Putri }\end{array}$ & 55 & 65 & 60 & 50 & 57,5 \\
\hline 39 & Hartono & 55 & 70 & 55 & 50 & 57,5 \\
\hline 40 & $\begin{array}{l}\text { Ulandar } \\
\text { i Nurul }\end{array}$ & 55 & 40 & 65 & 65 & 56,25 \\
\hline 41 & Hidayat & 40 & 40 & 75 & 65 & 55 \\
\hline 42 & $\begin{array}{l}\text { Kristini } \\
\text { nggrum } \\
\text { lubis } \\
\text { Desti }\end{array}$ & 70 & 40 & 60 & 50 & 55 \\
\hline 43 & $\begin{array}{l}\text { Zakaria } \\
\text { Pardom } \\
\text { uan }\end{array}$ & 74 & 50 & 55 & 40 & 54,75 \\
\hline 44 & $\begin{array}{l}\text { Isnaini } \\
\text { Rafi }\end{array}$ & 40 & 65 & 55 & 54 & 53,5 \\
\hline 45 & $\begin{array}{l}\text { Nurcah } \\
\text { yani } \\
\text { Rasyid }\end{array}$ & 40 & 68 & 55 & 50 & 53,25 \\
\hline 46 & $\begin{array}{l}\text { Khawar } \\
\text { in Nur }\end{array}$ & 40 & 50 & 55 & 65 & 52,5 \\
\hline 47 & $\begin{array}{l}\text { Yennita } \\
\text { Isnah }\end{array}$ & 45 & 40 & 80 & 40 & 51,25 \\
\hline 48 & $\begin{array}{l}\text { Harsela } \\
\text { Paula }\end{array}$ & 45 & 55 & 65 & 40 & 51,25 \\
\hline 49 & $\begin{array}{l}\text { Situmor } \\
\text { ang }\end{array}$ & 40 & 45 & 65 & 45 & 48,75 \\
\hline 50 & $\begin{array}{l}\text { Sari } \\
\text { Ade }\end{array}$ & 40 & 40 & 40 & 65 & 46,25 \\
\hline
\end{tabular}

Dengan keterangan rentang nilai dapat dilihat pada tabel 9

Tabel 9. Keterangan Rentang Nilai

\begin{tabular}{|c|c|c|c|c|}
\hline Nilai & $\begin{array}{l}\text { Bug } \\
\text { Finding }\end{array}$ & $\begin{array}{l}\text { Bug } \\
\text { Isolation }\end{array}$ & $\begin{array}{l}\text { Bug } \\
\text { Description }\end{array}$ & $\begin{array}{l}\text { Bug } \\
\text { Reporting }\end{array}$ \\
\hline $75-85$ & $\begin{array}{l}\text { sangat } \\
\text { menguasai }\end{array}$ & $\begin{array}{l}\text { sangat } \\
\text { menguasai }\end{array}$ & sangat jelas & $\begin{array}{l}\text { sangat } \\
\text { lengkap }\end{array}$ \\
\hline $65-74$ & menguasai & menguasai & jelas & lengkap \\
\hline $55-64$ & kurang & kurang & kurang & kurang \\
\hline $40-54$ & tidak bisa & tidak bisa & tidak bisa & tidak bisa \\
\hline
\end{tabular}

Nilai manual tersebut yang nantinya akan dibandingkan dengan nilai dari sistem yang telah dibuat. 
Berikut adalah rancangan diagram class yang ditunjukan oleh gambar 2 dan perancangan diagram antar tabel yang ditunjukan oleh gambar 3 .

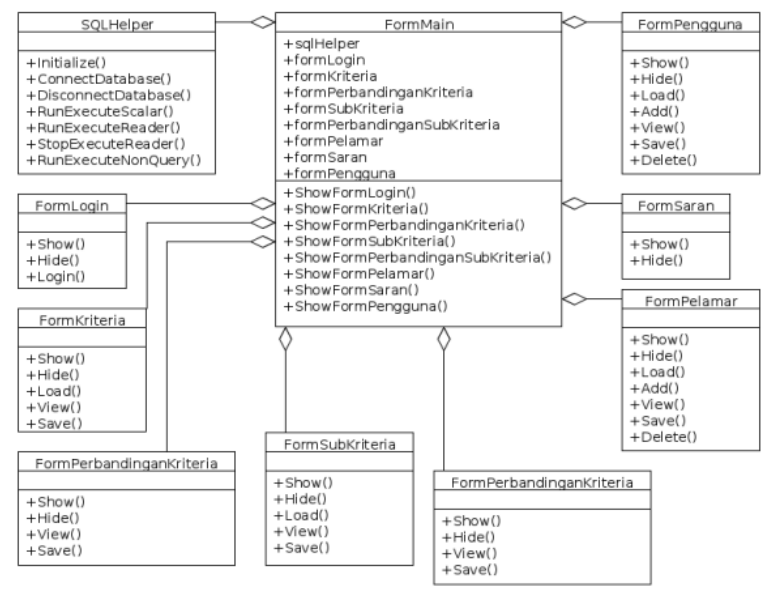

Gambar 2. Rancangan Diagram Class

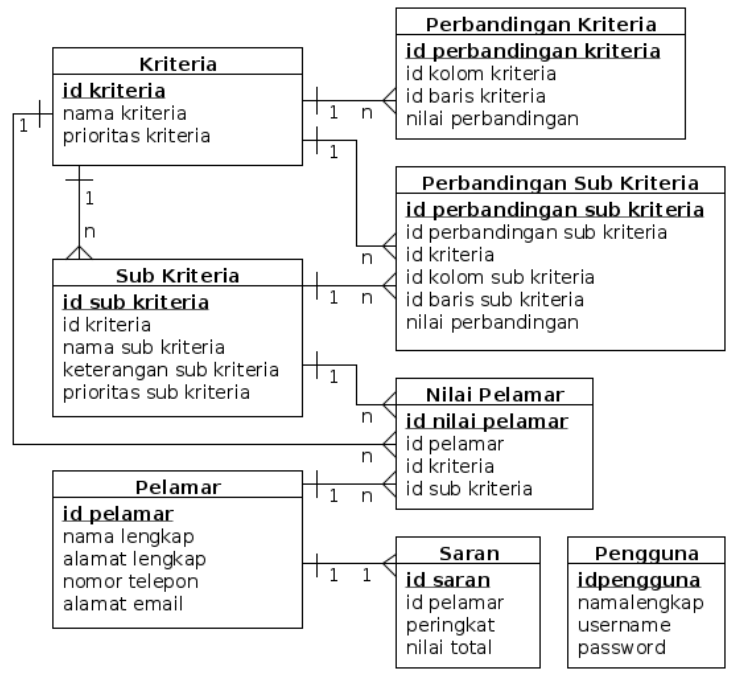

Gambar 3. Rancangan Diagram Antar Tabel

\section{Hasil dan Pembahasan}

Tujuan dibuatnya sistem dalam penelitian ini untuk membantu melakukan perhitungan penilaian terhadap pelamar Quality Assurance Tester di Gameloft Indoneisa Yogyakarta, sehingga tidak perlu lagi menggunakan perhitungan manual dan proses menjadi lebih mudah, akurat, dan transparan. Sistem secara langsung akan memproses penilaian peelamar dan mengurutkannya dari nilai tertinggi ke nilai terendah.

Proses pengambilan keputusan menggunakan sistem dapat dilihat pada gambar 5 sampai gambar 8 .

\section{Penentuan Kriteria}

Penentuan kriteria pada sistem dapat dilihat pada Gambar 5.

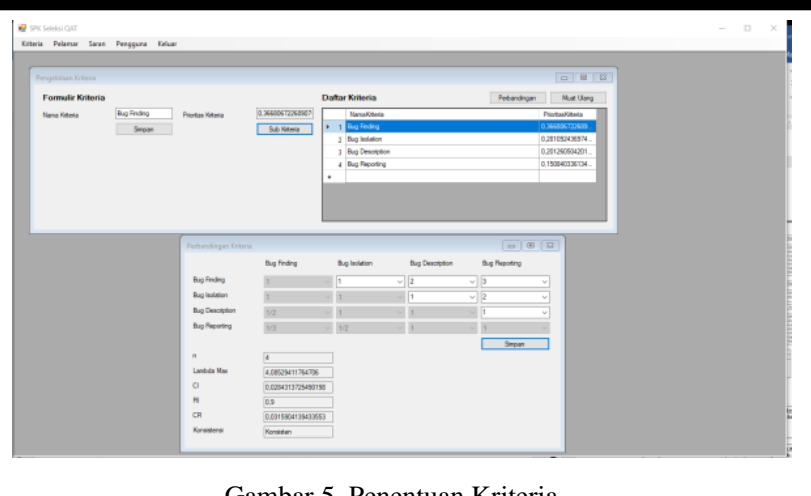

Gambar 5. Penentuan Kriteria

2. Penentuan Sub Kriteria

Penentuan Sub Kriteria pada sistem dapat dilihat pada Gambar 6.

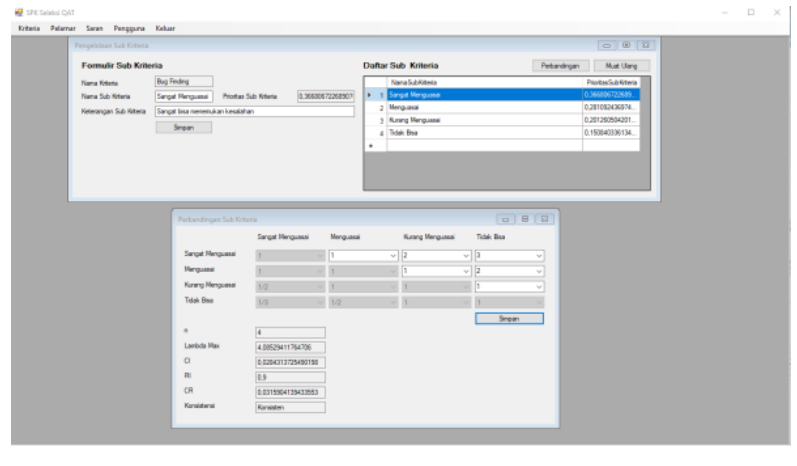

Gambar 6. Penentuan Sub Kriteria

\section{Form Pelamar}

Form Pelamar pada sistem dapat dilihat pada Gambar 7

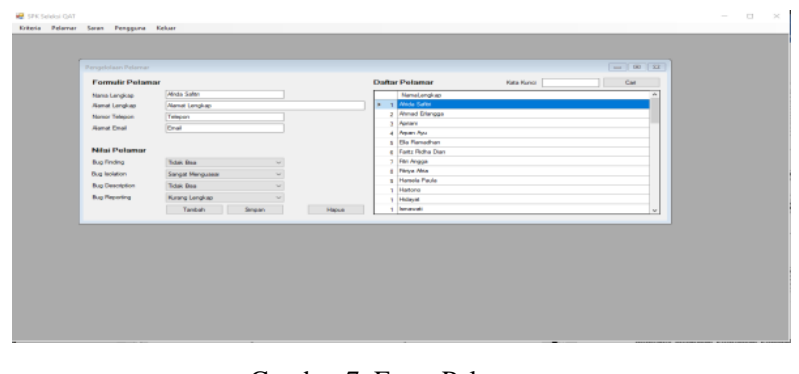

Gambar 7. Form Pelamar

\section{Form Saran}

Form saran atau form hasil, merupakan hasil akhir perhitungan dan sudah diurutkan melalui sistem, dapat dilihat pada Gambar 8.

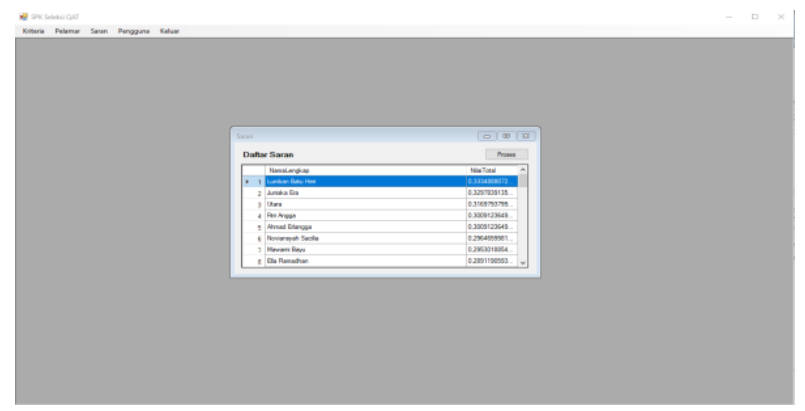


Berikut hasil perankingan perhitungan setelah menggunakan sistem, dapat dilihat pada Tabel 10.

Tabel 10. Hasil Perhitungan Sistem

\begin{tabular}{|c|c|c|}
\hline Peringakt & Nama & Nilai Total \\
\hline 1 & Lumban Batu Heri & 0,3335 \\
\hline 2 & Juniska Era & 0,3298 \\
\hline 3 & Utara & 0,3170 \\
\hline 4 & Fitri Angga & 0,3009 \\
\hline 5 & Ahmad Erlangga & 0,3009 \\
\hline 6 & Noviansyah Sacilia & 0,2965 \\
\hline 7 & Mawarni Bayu & 0,2953 \\
\hline 8 & Ella Ramadhan & 0,2891 \\
\hline 9 & Munthe Robi & 0,2877 \\
\hline 10 & Kurnia Ferry & 0,2787 \\
\hline 11 & Faritz Ridha Dian & 0,2768 \\
\hline 12 & Super Muhammad & 0,2768 \\
\hline 13 & Rohani Nurul & 0,2759 \\
\hline 14 & Wulandari Riri & 0,2647 \\
\hline 15 & Sihombing Desi & 0,2639 \\
\hline 16 & Pramesti M. & 0,2639 \\
\hline 17 & Arpan Ayu & 0,2598 \\
\hline 18 & Mislaili Dwi & 0,2593 \\
\hline 19 & Rosha Pangestu Ahmad & 0,2466 \\
\hline 20 & Ramayani Nur & 0,2466 \\
\hline 21 & Nuraini Dewi & 0,2454 \\
\hline 22 & Karuniyati Muhamad & 0,2442 \\
\hline 23 & Riski Randa & 0,2421 \\
\hline 24 & Apriani & 0,2413 \\
\hline 25 & Riati Ginting Fitri & 0,2413 \\
\hline 26 & Raslan Gatot & 0,2413 \\
\hline 27 & Ristiana Tama Jefry & 0,2376 \\
\hline
\end{tabular}

\begin{tabular}{|c|c|c|}
\hline 28 & Rohmawati Alvin & 0,2352 \\
\hline 29 & Ismawati & 0,2324 \\
\hline 30 & Mutiara Kencana Sandi & 0,2294 \\
\hline 31 & Reksosamudro Andika & 0,2293 \\
\hline 32 & Nababan Ilham & 0,2284 \\
\hline 33 & Fitriya Afria & 0,2269 \\
\hline 34 & Kurnia Awalia & 0,2262 \\
\hline 35 & Saputri Indah & 0,2229 \\
\hline 36 & Afrida Safitri & 0,2192 \\
\hline 37 & Nuratika Dwi & 0,2172 \\
\hline 38 & Riawan Putri & 0,2161 \\
\hline 39 & Hartono & 0,2161 \\
\hline 40 & Ulandari Nurul & 0,2152 \\
\hline 41 & Hidayat & 0,2140 \\
\hline 42 & $\begin{array}{l}\text { Kristininggrumlubis } \\
\text { Desti }\end{array}$ & 0,2121 \\
\hline 43 & Zakaria Pardomuan & 0,2088 \\
\hline 44 & Isnaini Rafi & 0,1976 \\
\hline 45 & Nurcahyani Rasyid & 0,1976 \\
\hline 46 & Khawarin Nur & 0,1948 \\
\hline 47 & Yennita Isnah & 0,1943 \\
\hline 48 & Harsela Paula & 0,1912 \\
\hline 49 & Situmorang & 0,1771 \\
\hline 50 & Sari Ade & 0,1705 \\
\hline
\end{tabular}

$\overline{\text { Dari hasil perhitungan sistem diatas, akan dilakukan }}$ perbandingan dengan perhitungan manual dari PT Gameloft Indonesia. Hasil Perbandingan dapat dilihat pada tabel 11 .

Tabel 11. Perbandingan Perhitungan Manual dan Sistem

\begin{tabular}{|c|c|c|c|c|c|c|}
\hline \multirow[t]{2}{*}{ No } & \multirow[t]{2}{*}{ Nama } & \multicolumn{2}{|c|}{ Hasil Sistem } & \multicolumn{2}{|c|}{ Hasil Manual } & \multirow{2}{*}{$\begin{array}{l}\text { Kesesu } \\
\text { aian }\end{array}$} \\
\hline & & $\begin{array}{l}\text { Has } \\
\text { il }\end{array}$ & $\begin{array}{l}\text { Perin } \\
\text { gkat }\end{array}$ & Hasil & $\begin{array}{l}\text { Peri } \\
\text { ngk } \\
\text { at }\end{array}$ & \\
\hline 1 & $\begin{array}{l}\text { Lumban } \\
\text { Batu Heri }\end{array}$ & $\begin{array}{l}0,33 \\
35\end{array}$ & 1 & 78,75 & 1 & Sesuai \\
\hline 2 & $\begin{array}{l}\text { Juniska } \\
\text { Era }\end{array}$ & $\begin{array}{l}0,32 \\
98\end{array}$ & 2 & 77,5 & 2 & Sesuai \\
\hline
\end{tabular}


Volume 11 No. 2 | Agustus 2021: 67-74

\begin{tabular}{|c|c|c|c|c|c|c|c|c|c|c|c|c|c|}
\hline 3 & Utara & $\begin{array}{l}0,31 \\
70\end{array}$ & 3 & 72,5 & 3 & Sesuai & 23 & $\begin{array}{l}\text { Riski } \\
\text { Randa }\end{array}$ & $\begin{array}{l}0,24 \\
21\end{array}$ & 23 & 64,5 & 22 & $\begin{array}{l}\text { Tidak } \\
\text { Sesuai }\end{array}$ \\
\hline 4 & $\begin{array}{l}\text { Fitri } \\
\text { Angga }\end{array}$ & $\begin{array}{l}0,30 \\
09\end{array}$ & 4 & 70 & 4 & Sesuai & 24 & Apriani & $\begin{array}{l}0,24 \\
13\end{array}$ & 24 & 63,75 & 24 & Sesuai \\
\hline 5 & $\begin{array}{l}\text { Ahmad } \\
\text { Erlangga }\end{array}$ & $\begin{array}{l}0,30 \\
09\end{array}$ & 5 & 68,75 & 5 & Sesuai & 25 & $\begin{array}{l}\text { Riati } \\
\text { Ginting } \\
\text { Fitri }\end{array}$ & $\begin{array}{l}0,24 \\
13\end{array}$ & 25 & 63,75 & 25 & Sesuai \\
\hline \multirow[t]{2}{*}{6} & Noviansy & 0,29 & 6 & 68,75 & 6 & Sesuai & & & & & & & \\
\hline & ah Sacilia & 65 & & & & & 26 & $\begin{array}{l}\text { Raslan } \\
\text { Gatot }\end{array}$ & $\begin{array}{l}0,24 \\
13\end{array}$ & 26 & 62,5 & 26 & Sesuai \\
\hline \multirow[t]{2}{*}{7} & Mawarni & 0,29 & 7 & 68,75 & 7 & Sesuai & & & & & & & \\
\hline & Bayu & 53 & & & & & 27 & $\begin{array}{l}\text { Ristiana } \\
\text { Tama }\end{array}$ & $\begin{array}{l}0,23 \\
76\end{array}$ & 27 & 62,25 & 27 & Sesuai \\
\hline \multirow[t]{2}{*}{8} & $\begin{array}{l}\text { Ella } \\
\text { Ramadha }\end{array}$ & $\begin{array}{l}0,28 \\
91\end{array}$ & 8 & 68,75 & 8 & Sesuai & & Jetry & & & & & \\
\hline & $\mathrm{n}$ & & & & & & 28 & $\begin{array}{l}\text { Rohmaw } \\
\text { ati Alvin }\end{array}$ & $\begin{array}{l}0,23 \\
52\end{array}$ & 28 & 62 & 28 & Sesuai \\
\hline \multirow[t]{2}{*}{9} & Munthe & 0,28 & 9 & 68 & 9 & Sesuai & & & & & & & \\
\hline & Robi & 77 & & & & & 29 & Ismawati & $\begin{array}{l}0,23 \\
24\end{array}$ & 29 & 61,75 & 30 & $\begin{array}{l}\text { Tidak } \\
\text { Sesuai }\end{array}$ \\
\hline \multirow[t]{2}{*}{10} & Kurnia & 0,27 & 10 & 67,75 & 10 & Sesuai & & & & & & & \\
\hline & Ferry & 87 & & & & & 30 & $\begin{array}{l}\text { Mutiara } \\
\text { Kencana }\end{array}$ & $\begin{array}{l}0,22 \\
94\end{array}$ & 30 & 61 & 29 & $\begin{array}{l}\text { Tidak } \\
\text { Sesuai }\end{array}$ \\
\hline \multirow[t]{2}{*}{11} & $\begin{array}{l}\text { Faritz } \\
\text { Ridha }\end{array}$ & $\begin{array}{l}0,27 \\
68\end{array}$ & 11 & 67.25 & 13 & $\begin{array}{l}\text { Tidak } \\
\text { Sesuai }\end{array}$ & & Sandi & & & & & \\
\hline & Dian & & & & & & 31 & $\begin{array}{l}\text { Reksosa } \\
\text { mudro }\end{array}$ & $\begin{array}{l}0,22 \\
93\end{array}$ & 31 & 60,75 & 31 & Sesuai \\
\hline \multirow[t]{2}{*}{12} & $\begin{array}{l}\text { Super } \\
\text { Muhamm }\end{array}$ & $\begin{array}{l}0,27 \\
68\end{array}$ & 12 & 66,75 & 11 & $\begin{array}{l}\text { Tidak } \\
\text { Sesuai }\end{array}$ & & Andika & & & & & \\
\hline & $\mathrm{ad}$ & & & & & & 32 & $\begin{array}{l}\text { Nababan } \\
\text { Ilham }\end{array}$ & $\begin{array}{l}0,22 \\
84\end{array}$ & 32 & 60,5 & 32 & Sesuai \\
\hline \multirow[t]{2}{*}{13} & Rohani & 0,27 & 13 & 66,5 & 12 & Tidak & & & & & & & \\
\hline & Nurul & 59 & & & & Sesuai & 33 & $\begin{array}{l}\text { Fitriya } \\
\text { Afria }\end{array}$ & $\begin{array}{l}0,22 \\
69\end{array}$ & 33 & 60 & 33 & Sesuai \\
\hline \multirow[t]{2}{*}{14} & Wulandar & 0,26 & 14 & 66,5 & 14 & Sesuai & & & & & & & \\
\hline & i Riri & 47 & & & & & 34 & $\begin{array}{l}\text { Kurnia } \\
\text { Awalia }\end{array}$ & $\begin{array}{l}0,22 \\
62\end{array}$ & 34 & 60 & 34 & Sesuai \\
\hline \multirow[t]{2}{*}{15} & Sihombin & 0,26 & 15 & 66 & 15 & Sesuai & & & & & & & \\
\hline & g Desi & & & & & & 35 & $\begin{array}{l}\text { Saputri } \\
\text { Indah }\end{array}$ & $\begin{array}{l}0,22 \\
29\end{array}$ & 35 & 58 & 35 & Sesuai \\
\hline \multirow[t]{2}{*}{16} & Pramesti & 0,26 & 16 & 66 & 16 & Sesuai & & & & & & & \\
\hline & M. & 39 & & & & & 36 & $\begin{array}{l}\text { Afrida } \\
\text { Safitri }\end{array}$ & $\begin{array}{l}0,21 \\
92\end{array}$ & 36 & 57,75 & 36 & Sesuai \\
\hline \multirow[t]{2}{*}{17} & Arpan & 0,25 & 17 & 66 & 17 & Sesuai & & & & & & & \\
\hline & Ayu & 98 & & & & & 37 & $\begin{array}{l}\text { Nuratika } \\
\text { Dwi }\end{array}$ & $\begin{array}{l}0,21 \\
72\end{array}$ & 37 & 57,5 & 37 & Sesuai \\
\hline \multirow[t]{2}{*}{18} & Mislaili & 0,25 & 18 & 65,75 & 18 & Sesuai & & & & & & & \\
\hline & Dwi & 93 & & & & & 38 & $\begin{array}{l}\text { Riawan } \\
\text { Putri }\end{array}$ & $\begin{array}{l}0,21 \\
61\end{array}$ & 38 & 57,5 & 38 & Sesuai \\
\hline \multirow[t]{2}{*}{19} & Rosha & 0,24 & 19 & 65,5 & 19 & Sesuai & & & & & & & \\
\hline & $\begin{array}{l}\text { Pangestu } \\
\text { Ahmad }\end{array}$ & 66 & & & & & 39 & Hartono & $\begin{array}{l}0,21 \\
61\end{array}$ & 39 & 57,5 & 39 & Sesuai \\
\hline 20 & $\begin{array}{l}\text { Ramayan } \\
\text { i Nur }\end{array}$ & $\begin{array}{l}0,24 \\
66\end{array}$ & 20 & 65,25 & 20 & Sesuai & 40 & $\begin{array}{l}\text { Ulandari } \\
\text { Nurul }\end{array}$ & $\begin{array}{l}0,21 \\
52\end{array}$ & 40 & 56,25 & 40 & Sesuai \\
\hline 21 & $\begin{array}{l}\text { Nuraini } \\
\text { Dewi }\end{array}$ & $\begin{array}{l}0,24 \\
54\end{array}$ & 21 & 65 & 21 & Sesuai & 41 & Hidayat & $\begin{array}{l}0,21 \\
40\end{array}$ & 41 & 55 & 41 & Sesuai \\
\hline 22 & $\begin{array}{l}\text { Karuniyat } \\
\text { i } \\
\text { Muhama } \\
\text { d }\end{array}$ & $\begin{array}{l}0,24 \\
42\end{array}$ & 22 & 64,75 & 23 & $\begin{array}{l}\text { Tidak } \\
\text { Sesuai }\end{array}$ & 42 & $\begin{array}{l}\text { Kristinin } \\
\text { ggrumlub } \\
\text { is Desti }\end{array}$ & $\begin{array}{l}0,21 \\
21\end{array}$ & 42 & 55 & 42 & Sesuai \\
\hline
\end{tabular}




\begin{tabular}{|c|c|c|c|c|c|c|}
\hline 43 & $\begin{array}{l}\text { Zakaria } \\
\text { Pardomu } \\
\text { an }\end{array}$ & $\begin{array}{l}0,20 \\
88\end{array}$ & 43 & 54,75 & 43 & Sesuai \\
\hline 44 & $\begin{array}{l}\text { Isnaini } \\
\text { Rafi }\end{array}$ & $\begin{array}{l}0,19 \\
76\end{array}$ & 44 & 53,75 & 44 & Sesuai \\
\hline 45 & $\begin{array}{l}\text { Nurcahya } \\
\text { ni Rasyid }\end{array}$ & $\begin{array}{l}0,19 \\
76\end{array}$ & 45 & 53,75 & 45 & Sesuai \\
\hline 46 & $\begin{array}{l}\text { Khawarin } \\
\text { Nur }\end{array}$ & $\begin{array}{l}0,19 \\
48\end{array}$ & 46 & 53,75 & 46 & Sesuai \\
\hline 47 & $\begin{array}{l}\text { Yennita } \\
\text { Isnah }\end{array}$ & $\begin{array}{l}0,19 \\
43\end{array}$ & 47 & 51,25 & 47 & Sesuai \\
\hline 48 & $\begin{array}{l}\text { Harsela } \\
\text { Paula }\end{array}$ & $\begin{array}{l}0,19 \\
12\end{array}$ & 48 & 51,25 & 48 & Sesuai \\
\hline 49 & $\begin{array}{l}\text { Situmora } \\
\text { ng }\end{array}$ & $\begin{array}{l}0,17 \\
71\end{array}$ & 49 & 48,75 & 49 & Sesuai \\
\hline $\mathbf{5 0}$ & Sari Ade & $\begin{array}{l}0,17 \\
05\end{array}$ & 50 & 46,25 & 50 & Sesuai \\
\hline
\end{tabular}

Dari tabel 11 diketahui bahwa banyak hasil sistem yang sesuai dengan hiungan manual sebanyak 43 dan banyak hasil sistem yang tidak sesuai dengan fakta sebanyak 7. Tabel 12 menunjukan jumlah kesesuaian perbandingan hasil.

Tabel 12. Jumlah Kesesuain Perbandingan Hasil

\begin{tabular}{ccc}
\hline No & Keterangan & Jumlah \\
\hline $\mathbf{1}$ & Data sesuai & 43 \\
\hline $\mathbf{2}$ & Data tidak sesuai & 7 \\
\hline $\mathbf{3}$ & Jumlah & 50 \\
\hline
\end{tabular}

Dari tabel 12 dapat diketahui bahwa persentasi hasil sistem yang sesuai dengan perhitungan manual adalah $86 \%$, dengan perhitungan dijabarkan sebagai berikut :

$$
\begin{gathered}
\text { Persentase }=\frac{\text { Data Sesuai }}{\text { Jumlah Total Data }} \times 100 \% \\
\text { Persentase }=\frac{43}{50} \times 100 \%=86 \%
\end{gathered}
$$

\section{Kesimpulan}

Berdasarkan penelitian yang telah dilakukan maka dapat dibuat kesimpulan sebagai berikut. Berdasarkan uji validitas hasil dapat diketahui bahwa sistem pendukung keputusan penyeleksian Quality Assurance Tester di PT Gameloft Indonesia yang telah dibuat memiliki perhitungan dan hasil dengan kesesuaian
$86 \%$ dari perhitungan dan hasil secara manual. Berdasarkan uji fungsionalitas dapat diketahui bahwa sistem pendukung keputusan penyeleksian Quality Assurance Tester di PT Gameloft Indonesia yang telah dibuat dapat melakukan semua fungsi dan sub fungsi dengan baik dan benar.

Saran untuk peneliti selanjutnya untuk mengecilkan rentang nilai dari hitungan manual yang di gunakan, agar dapat memaksimalkan persentase perbandingan perhitungan antara perhitungan sistem dan perhitungan manual

\section{Daftar Rujukan}

[1] Alda, M. (2021). Rekayasa Perangkat Lunak Berorientasi Objek. bandung Penerbit Media Sains Indoesia.

[2] Fitriani, P. dan Alasi, T. S. (2020). Sistem Pendukung Keputusan dengan Metode WASPAS, COPRAS dan EDAS: Menentukan Judul Skripsi Mahasiswa. Medan: Yayasan Kita Menulis.

[3] Ginting, D. Y. B., Ginting, R. dan Sembiring, D. J. M. (2020). Sistem Pendukung Keputusan Dengan Menggunakan Metode Analytic Hierarchy Process (AHP). Yogyakarta: Penerbit Andi.

[4] Hendrikson,E. (2013). Explore It! Reduce and Increase Confidence with Exploratory Testing. Raleigh: Pragmatic Bookshelf

[5] Malau, Y. (2020). Sistem Pendukung Keputusan Pemilihan Kategori Promosi Produk Menggunakan Metode Profile Matching (Studi Kasus : Minimarket). Jurnal MATRIK, Vol. 19, No. 2, ISSN: 2476-9843, 339-346.

[6] Poningsih, Saragih, R., Sinaga, S. B., Sinaga J. L. S., Hasibuan, F. A., Agustina, N., Alifah, W., Deswiyan, I. A., Widiastari, A., Apriani, T., Wulandika, S. dan Solikhun. (2020). Sistem Pendukung Keputusam: Penerapan dan 10 Contoh Studi Kasus. Medan: Yayasan Kita Menulis.

[7] Pratama, A. R. dan Ismarmiaty. (2020). Sistem Pendukung Keputusan Perekrutan Karyawan PT. Cakra Mobilindo Menggunakan Metode Simple Additive Weighting. Matrik: Jurnal Manajemen, Teknik Informatika dan Rekayasa Komputer, Vol. 20, No. 1, ISSN: 2476-9843, pp. 117-128.

[8] Sembiring, F., Fauzi, T. M., Khalifah, S., Khotimah, A. K. dan Rubiati, Y. (2020). Sistem Pendukung Keputusan Penerima Bantuan Covid 19 menggunakan Metode Simple Additive Weighting (SAW) (Studi Kasus: Desa Sundawenang). Explore: Jurnal Sistem Informasi Dan Informatika (Telekomunikasi, Multimedia Dan Informatika, Vol. 11, No. 2, ISSN: 2087-2062, 97-101.

[9] Sholehah, N. dan Maspiyanti, F. (2020). Sistem Pendukung Keputusan Pemilihan Guru Terbaik Menggunakan Metode Simple Additive Weighting Dan Topsis. Jurnal Ilmiah Informatika (JIF), Vol. 8, No. 2, ISSN: 2337-8379, 125-135.

[10] Somya, R. dan Wahyudi, A. (2020). Sistem Pendukung Keputusan Perekrutan Karyawan Menggunakan Metode TOPSIS di PT Visionet Data Internasional. Jurnal Informatika, Vol. 7, No.2, ISSN: 2355-6579, 107-115.

[11] Sukamto, Fitriansyah, A. dan Pratama, R. P. (2020). Sistem Pendukung Keputusan Penentuan Matakuliah Pilihan Menggunakan Metode TOPSIS (Studi Kasus : Prodi S1 Sistem Informasi FMIPA Universitas Riau). Jurnal Teknologi Informasi \& Komunikasi Digital Zone, Vol. 11, No. 1, ISSN: 2477-3255, 43-58.

[12] Waruwu, T. S. dan Nasution, S. (2020). Sistem Pendukung Keputusan Pemilihan Investasi Saham Berbasis Web Menggunakan Metode SMART. Jurnal Mahajana Informasi, Vol. 5, No. 1, ISSN : 2527-8290, 8-13. 